\title{
Optimization of Paraphrase Learning for Academic Writing in Student of Midwifery
}

\author{
Rati Purnama Sari $\left.{ }^{1 *}\right)$, Zul Amri ${ }^{2}$
}

\author{
${ }^{1}$ Midwifery Department, Poltekkes Kemenkes Padang \\ ${ }^{2}$ Nutrition Department, Poltekkes Kemenkes Padang \\ *Corresponding author. Email: ratipurnamasariab@gmail.com
}

\begin{abstract}
Paraphrase is a way to prevent plagiarism. Many students did not understand academic writing, especially about paraphrasing, though they are required to make some field practice and final project reports. This study aims to analyze the changes in the understanding of the students about paraphrase. This study used one group pre-post test design was conducted on Agust 2019. Samples of this study were 34 students. The understanding of the students was measured using online exam and practice sheets which analyze used Wilcoxon and Freidman test. The results showed the mean of the understanding level after paraphrase learning was higher than before learning 43.32 \pm 9.49 . The understanding level was significantly different between pre and posttest $98.63 \pm 3.94$. Paraphrase learning could enhance the understanding level of the student about paraphrase. It should be taken into consideration to improve academic writing of the students.
\end{abstract}

Keywords: Paraphrase, plagiarism, students of midwifery

\section{INTRODUCTION}

Awareness of the writings of others with the correct ethics is still often ignored. Ease of searching information makes someone could copy others. If this continues, it will encourage an increase in plagiarism. Whereas plagiarism is an important thing that can have a fatal impact on the career development of a professional, especially in the academic environment [1].

Some students often did plagiarism. For example, using someone else's paper by just replacing the cover sheet to change be his name. Another act is writing a thesis by duplicating a theory that is on someone else without reading the source. Actions that also include plagiarism that many students do are making academic papers with blog resources. Moreover, there was a student as if conducted a field study, even it only based on what he read from someone's blog [2].

Plagiarism is a problem in many universities. A study among undergraduate students in Spanish and Mexican shows many students did plagiarism even Spanish had a higher. The majority of participants conveyed the internet as one of the main sources [3]. Another study in Pakistan had a similar finding. Awareness of undergraduate students about plagiarism was under the expected numbers. Most of them agreed to plagiarism that they did. This finding shows that there are still many who do not understand about plagiarism [4]

Indonesian Goverment has issued regulations governing plagiarism, namely in the Ministry of National Education Regulation (Permendiknas) No. 17 of 2010 concerning Prevention and prevention of Plagiarism in tertiary institutions. Article 1 states that "Plagiarism is a deliberate or unintentional provision in obtaining or attempting to obtain credit or value for scientific work, by quoting part or all of the work and/or scientific work of another party recognized as scientific work, without stating the source in a manner appropriate and adequate." Students who are proven to have committed plagiarism as stipulated in Permendiknas Number 17 of 2010 Article 12, are given sanctions in sequence from the lightest to the most severe [5].

Paraphrasing is a way of conveying information from other writers to the reader using his own words as an appreciation to the writer [6]. Not only as a form of appreciation for the writers who used his work, but also prevented plagiarism. Paraphrase represents that the writer has done the reading process and analyzes the reading source. Through the correct ethics of writing the writer allows the reader to find the source that is referred [7].

Based on obsrvations from several students reports found in the form of copies from sources. The lack of understanding and motivation in academic writing became urgency in this matter. The description above is formulated that the crucial problem in this research is there are still many students who have not used the correct paraphrasing technique in report writing. The purpose of this study was to determine the optimization of paraphrase learning in scientific writing to students in the Midwifery Department of Poltekkes Kemenkes Padang. 


\section{METHOD}

This study used one group pre-post test design was conducted on Agust 2019. Populations of this study were students of midwifery department of Poltekkes Kemenkes Padang. The samples were final-year students of midwifery department of Poltekkes Kemenkes Padang. The sampling technique used total sampling as many as 34 students. The understanding of the students was measured using online exam and practice sheets.

Students were asked to do pre-test online with multiple choice. Then students were given paraphrase learning through lecture and discussion techniques. Next, students were given assignments to do online exercises as homeworks, then discussed in the class at their next meeting with the Teams-Games-Tournament methods. The task assesment instrument consists of 3 indicators. Writing is assessed from the aspect of to the writing rules in Bahasa and understood easily, the ability to write in different sentences with relevant and appropriate meanings according to the source; the writing style pays attention, and the timeliness of assignments. The students were given the exercises three times. On the last meeting, students have taken a post-test online consisting of the same questions at the pre-test.

The instrument in this study used the exercises and pre-post test. Data from the pre-post test results and exercises done by students were then analyzed statistically. Results of pre-post test analysis with the Wilcoxon test. While the results of the exercises were analyzed using the Wilcoxon and Friedman tests.

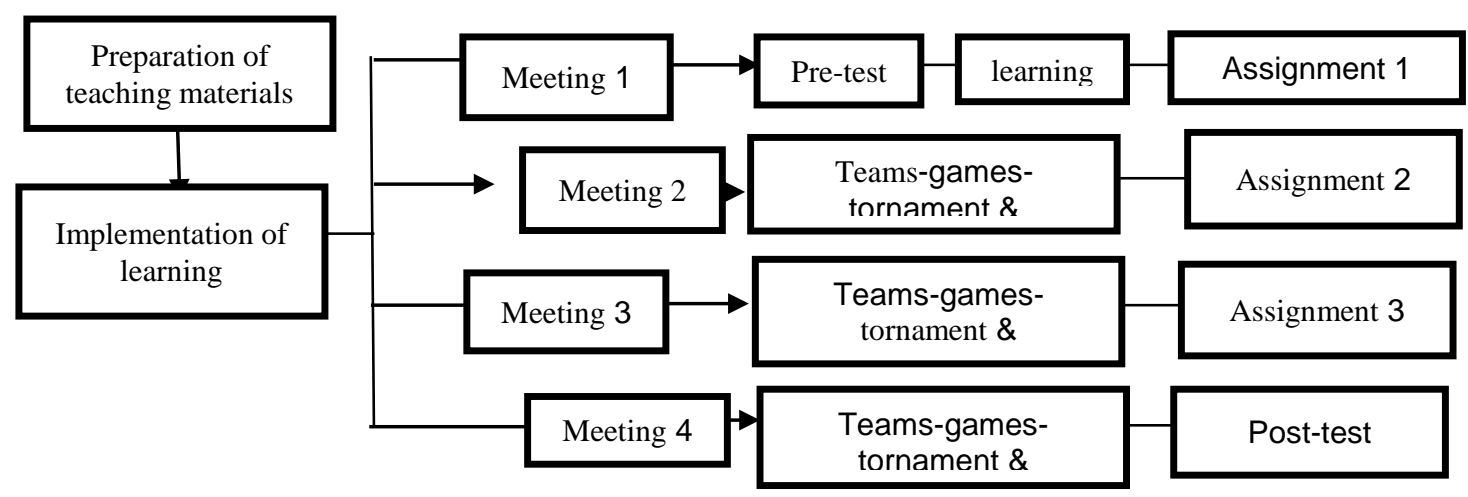

Figure 1. Paraphrase learning flowchart

\section{Results}

\section{RESULT AND DISCUSSION}

Analysis of answer to the pre-test question

Student pre-test scores were analyzed based on the number of students who answer correctly and incorrectly on each question, presented in the following graph:

Analysis of answers to the pre-test questions

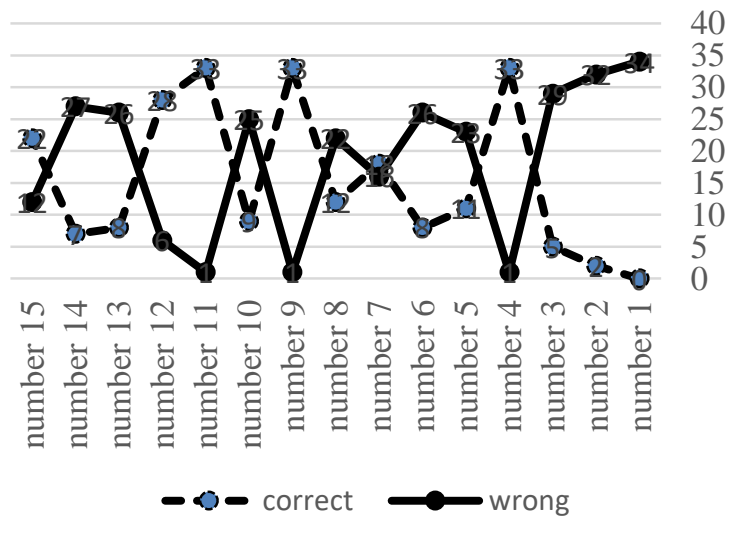

Figure 1. Analysis of answer to the pre-test question

Based on the pre-test results was known that the questions most frequently answered incorrectly by students were about the understanding of paraphrases (questions number 1,2,3). Some students claimed to have heard and studied paraphrasing at the school level but did not remember well Almost students knew the meaning of plagiarism and actions that may and may not be done by students in academic writing (question number 4). However, most students are still not aware of the regulations governing the prevention and control of plagiarism (question number 5). A minority of students answered correctly the question of the heaviest sanctions of plagiarism (question number 6). Half of the students the acts of plagiarism (questions number 7, 8 and 9). While learning, students told several cases of plagiarism that had been committed by a character and which harmed the perpetrator's career. Many students said ever duplicate sources, especially from the internet. Some students did not understand the technique of paraphrasing writing. Questions about the right paraphrase sentences are still answered incorrectly by the majority of students (questions number 10-15). Students are invited to analyze each choice of answers making it easier for students to understand. 
An analysis of differentiating between pre-test and post-test scores to determine is learning has been done optimally. The analysis of pre-post test scores was in the table below.

Table 1. Analysis of Pre-post test scores

\begin{tabular}{lccc}
\hline $\begin{array}{c}\text { Evaluation } \\
\text { scores }\end{array}$ & Pre-test & Post-test & p-value* \\
\hline - n & 34 & 34 & \\
- mean \pm SD & $43.32 \pm 9.49$ & $98.63 \pm 3.94$ & \\
- median & 40 & 100 & $<0.001$ \\
- minimum & 26 & 86.70 & \\
- maximum & 67 & 100 & \\
\hline \multicolumn{4}{c}{$*$ Wilcoxon test }
\end{tabular}

Based on the data above was found mean in the pretest was 43.32. While on post scores, the class average is 98.63. Wilcoxon test results showed a significant difference in student scores at the pre-test and the posttest. The scores obtained by students at the post-test were higher than the scores at the pre-test.

\section{Analysis of student exercise score}

A-three times exercise also carried out statistical tests. This test to assess whether there are differences in the ability to write paraphrases in students.

Table 2. Analysis of students exercises score

\begin{tabular}{ccccc} 
Excercise & $\begin{array}{c}\mathbf{1} \\
(\boldsymbol{n = 3 4 )}\end{array}$ & $\begin{array}{c}\mathbf{2} \\
(\boldsymbol{n}=\mathbf{3 4})\end{array}$ & $\begin{array}{c}\mathbf{3} \\
(\boldsymbol{n}=\mathbf{3 4})\end{array}$ & $\begin{array}{c}\text { p- } \\
\text { value** }\end{array}$ \\
\hline mean \pm SD & $78.99 \pm 7.10$ & $80.60 \pm 5.83$ & $82.71 \pm 7.22$ & \\
minimum & 60.80 & 61.60 & 72.00 & 0.018 \\
maximum & 90.40 & 90.40 & 96.00 & \\
\hline
\end{tabular}

Based on the data above was found mean in the first exercise was 78.99, the second exercise was 80.60, and the third exercise was 82.71. Based on the Friedman test was found statistically were significant differences in the grades of students from the three exercises. Then, to assess the significant differences in each group, the following Posthoc test with Wilcoxon was conducted below.

Table 3. Analysis of Students score for each excerises

\begin{tabular}{cccc}
\hline & Excercis & $\begin{array}{c}\text { p- } \\
\text { value }^{* * * *}\end{array}$ & Conclusion \\
\hline $\begin{array}{c}\text { Excercise } \\
1\end{array}$ & $\begin{array}{c}\text { Excercise } \\
2\end{array}$ & 0.248 & $\begin{array}{c}\text { No significant } \\
\text { difference }\end{array}$ \\
\hline $\begin{array}{c}\text { Excercise } \\
2\end{array}$ & $\begin{array}{c}\text { Excercise } \\
3\end{array}$ & 0.025 & $\begin{array}{c}\text { significant } \\
\text { difference }\end{array}$ \\
\hline $\begin{array}{c}\text { Excercise } \\
3\end{array}$ & $\begin{array}{c}\text { Excercise } \\
1\end{array}$ & 0.028 & $\begin{array}{l}\text { significant } \\
\text { difference }\end{array}$ \\
\hline \multicolumn{3}{c}{$* *$ Wilcoxon test } &
\end{tabular}

The results of the first and second exercises have not shown significant differences. While the results of the 2nd and 3rd training test showed a significant difference, so did the 1 st and 3rd exercises. So, we could conclude there was an increase in paraphrasing writing skills in students.

Besides that, students said they understood more and could paraphrase. They promised using paraphrase to avoid plagiarism, especially in writing their final project.

\section{Discussion}

Result of this study shows a significant difference between before and after scores in the paraphrase ability of student of Midwifery Department of Poltekkes Kemenkes Padang. Based on these results, also known that the exercises undertaken by student designation have increased paraphrasing academic writing.

Teaching used the question and answer discussion method. The discussion about the exercise was done the students through the link provided previously. The discussion was carried out using the cooperative learning method with the Teams-Games-Tournament (TGT) approach. This technique is by allowing students to collect points for their team. This technique increases student activity. They enthusiastically complete and collaborate. Students also feel that they can contribute because they can assess their friends.

The exercises done by students are then discussed in class using the cooperative learning method with the Teams-Games-Tournament approach. Writing students who need to correct their practice results are allowed to come to the front of the class and present their writing to be analyzed together. The exercises done by students are then discussed in class using the cooperative learning method with the Teams-Games-Tournament approach.

Besides aiming to improve the ability of students in writing, it also increases confidence in the student [8]. Another study showed TGT is more effective compared to the lecture teaching method in padagogic. This is based on indicators of student achievement attitude asa well as the potive attitude of students in the classroom [9].

Based on the results of exercises, some students did it well. Others write sentences with the use of meaning that is relevant to the original sentence but still use a simple writing style for scientific writing. Some students have good enough writing styles but use some words are incorrected to inappropriate meanings.

Student-centered learning gave a positive effect on the students. The score of students could enhance higher when they learned using student-centered learning than teacher-centered learning [10]. A previous study was obtained results in the method of paraphrasing in the learning process of changing poetry 
into proses/narration. This evident from the increase in student grades from the initial test to the first cycle and second cycle [11].

\section{CONCLUSION}

Evaluate the implementation of learning through pre-post tests and exercises. There was a significant difference in the paraphrase ability of students in the Midwifery Department of Poltekkes Kemenkes Padang. Academic writing, especially, paraphrase used to support the students to write their reports. The evaluation result of this study is hoped to become one of the considerations as an alternative solution in overcoming the issue of paraphrase by students.

\section{REFERENCES}

[1] Deepublish.: Teknik Menulis Karya Tulis dengan Parafrase untuk Menghindari Plagiarisme. (2016) https://penerbitdeepublish.com/teknik-menulispenerbit-buku-g055

[2] Indriati, Etty.: Strategi Hindari Plagiarisme. Gramedia. Jakarta. pp. 127-132 (2015)

[3] Forgas, R.C., Negre, J.S., Nava, C., Serrano, L., Academic Cyberplagiarism: A descriptive and comparative analysis of the prevalance amongst the undergraduate students at tecmilenio university (Mexico) and Balearic Islands University (Spain). Edulearn10 Proceedings. Pp 3450-3455 (2010)

[4] Ramzan, M., Munir, M.A, Siddique, N. et al. Awareness about plagirism amongst university students in Pakistan. High Education 64, 73-84 (2012) DOI:1007/s10734-011-9481-4

[5] Presiden Republik Indonesia.: Peraturan Menteri Pendidikan Nasional Republik Indonesia Nomor 17 Tahun 2010 tentang Pencegahan dan Penanggulangan Plagiat di Perguruan Tinggi. pp. 6-8 (2010)

[6] Isakov, L and Klassen, C. Paraphrasing Without Plagiarizing. Douglascollege Learning Centre. pp.1 (2014) https://www.douglascollege.ca//media/0400EA745B254FC4B879D3740B65B8 25.ashx?la=en

[7] Zuntriana, Ari.: Membuat Kutipan, Parafrasa dan Ringkasan Sumber-Sumber Referensi. pp. (4-6) http://repository.uinmalang.ac.id/2189/1/Membuat\%20kutipan\%2C \%20parafrasa\%20dan\%20ringkasan\%20sumbersumber\%20referensi.pdf

[8] Marhaeni, A.A.I.N, et al. Bahan Ajar Pekerti.: Pelatihan Keterampilan dasar Teknik Instuksional. Jakarta: RajaGrafindo. pp. 116122 (2018)

[9] Saman, A., Hossain, A., and Rahman, S.: Effects of using Teams Games Tournaments (TGT)
Cooperative Technique for Learning Mathematics in Secondary Scholl of Bangladesh. Malaysian Online Journal of Educational Technology. 3(3). (2015)

[10] Nurjannah I, Husniyah F, Harjanto T.: TeacherCentered Learning and Student-Centered Learning Approaches in Nursing School: Which one is Better? Belitung Nursing Journal. 3(2). pp. 65-72 (2017)

[11] Usman, Raja: Penggunaaan Metode Parafrase untuk Meningkatkan Kemmapuan Menulis Parafrase Puisi ke prosa terhadap Hasil Belajar Siswa Kelas II SMP Al-Ittihat Pekanbaru. Jurnal Sorot. 10 (2) pp. 169-178 (2015) 